Matematikai Közlemények

IX. kötet, 2021

doi:10.20312/dim.2021.02

\title{
Az általánosított hiperbolikus oktonióalgebrákról
}

\author{
Péntek Kálmán \\ ELTE SEK TTMK \\ Savaria Matematikai Tanszék \\ pentek.kalman@sek.elte.hu
}

\begin{abstract}
ÖSSZEFOGLALÓ. A dolgozatban általánosítjuk Macfarlane $\mathrm{M}$ klasszikus hiperbolikus kvaternióit és megkonstruáljuk az általánosított hiperbolikus kvaternióinak $\mathbb{M}_{\alpha \beta}$ struktúráját. Az általánosított Cayley-Dickson eljárás felhasználásával e struktúrából megalkotjuk az általánosított hiperbolikus oktoniók $\mathbb{O}_{\alpha \beta \gamma}^{H}$ nem kommutatív és nem asszociatív algebráját. Az utolsó fejezetben megkonstruáljuk az általánosított hiperbolikus oktoniók vektor-mátrix reprezentációját.
\end{abstract}

\begin{abstract}
In the paper we generalize Macfarlane's classical hyperbolic quaterninons $\mathrm{M}$, and we construct the structure of generalized hyperbolic quaternions $\mathbb{M}_{\alpha \beta}$. Based of the generalized Cayley-Dickson process of this structure we yield the non-commutative and non-associative algebras of generalized hyperbolic octonions $\mathbb{O}_{\alpha \beta \gamma}^{H}$. In the last section we construct the vector-matrix representation of generalized hyperbolic octonions.
\end{abstract}

\section{Bevezetés}

Sir William Rowan Hamilton (1805 - 1865) ír matematikus, fizikus és csillagász a komplex számok struktúrájának általánosításaként alkotta meg a kvaterniókat. A kvaterniók képzetes egységei közötti, áttörést jelentő

$$
i^{2}=j^{2}=k^{2}=i \cdot j \cdot k=-1
$$

összefüggést 1843. október 16-án ismerte fel. Dublinban az Ír Tudományos Akadémia ülésére tartott gyalogosan, ahol aznap éppen ő elnökölt. A Királyi Csatorna hidjához érve naplója bejegyzése szerint villámcsapásként érte a felismerés. A pillanat hevületében zsebkésével a híd korlátjába véste a felfedezett összefüggést, amely egyértelmüen a probléma megoldását jelentette. Hamilton ezután teljes hátralevő életét a kvaterniók elmélete minél teljesebb kidolgozásának szentelte. (HAMILTON, 1844,1847)

Nem sokkal Hamilton felfedezése után John Thomas Graves (1806 - 1870) ír, majd Arthur Cayley (1821 - 1895) angol jogász és matematikus egymástól függetlenül megalkották az oktoniók struktúráját. A XIX. század második felében jónéhány más, a számfogalom általánosításaként felépített rendszer is napvilágot látott. Ezek egyike volt az Alexander Macfarlane (1851 - 1913) skót származású amerikai matematikus és fizikus által 1891-ben megalkotott hiperbolikus kvaterniók algebrája. Ezeket a matematikai struktúrákat egészen a XX. század harmincas éveinek végéig hiperkomplex rendszereknek nevezték utalva arra, hogy a komplex számok általánosításaiként alakultak ki. Manapság ezekre a struktúrákra inkább a 
(test feletti) algebrák elnevezést használják. (CAYLEY, 1889), (MACFARLANE, 1900), (KANTOR - SZOLODOVNYIKOV, 1985), (ROSENFELD, 1997).

Ebben a dolgozatban elöször általánosítjuk az általánosított kvaternióalgebrák mintájára Macfarlane hiperbolikus kvaternióit és áttekintjük e struktúrák legfontosabb tulajdonságait. A témát magyar nyelven részletesen tárgyalja pl. PÉNTEK (2020) dolgozata. Ezután az általánosított hiperbolikus kvaterniók struktúrájának Cayley-Dickson-féle megkettőzési eljárásával építjük fel az általánosított hiperbolikus oktoniók algebráját. Ez az algebra nem kommutatív és nem is asszociatív, de reprezentálható alkalmas Zorn-féle vektor-mátrixok segítségével. Ezen reprezentációs tétel bizonyítása jelenti dolgozatunk fö eredményét.

\section{Az általánosított komplex számok és az általánosított hiperbolikus kvaterniók}

Ebben a fejezetben összefoglaljuk azokat a legfontosabb elözetes ismereteket, amelyek feltétlenül szükségesek a dolgozat fö részét képező általánosított hiperbolikus oktoniók tárgyalásához.

Jelölje $\{\mathbb{R},+$,$\} a valós számok testét a 0$ összeadási és 1 szorzási neutrális elemmel. Ekkor a

$$
\mathbb{C}_{\gamma}:=\{a+b \cdot i: a, b \in \mathbb{R}, i \notin \mathbb{R}\}
$$

alakú kifejezéseket az általánositott komplex számok halmazának nevezzük akkor és csakis akkor, ha az $\{1, i\}$ komplex egységek eleget tesznek az alábbi szorzási szabályoknak:

$$
1 \cdot 1=1,1 \cdot i=i \cdot 1=i, i^{2}=-\gamma,
$$

ahol $\gamma \in \mathbb{R}$ egy tetszöleges rögzített valós paraméter.

A $\mathbb{C}_{\gamma}$ halmazban egy skalárral való szorzás, összeadás, valamint a (2) alapján az algebrák szokásos konstruálási szabályai szerint még egy szorzás múvelet is értelmezhető az alábbi módon. Tetszőleges $r \in \mathbb{R}, a+b \cdot i, a^{\prime}+b^{\prime} \cdot i \in \mathbb{C}_{\gamma}$ esetén legyen

$$
\begin{gathered}
r \cdot(a+b \cdot i):=(r \cdot a)+(r \cdot b) \cdot i \text { a skalárral való szorzás, } \\
(a+b \cdot i)+\left(a^{\prime}+b^{\prime} \cdot i\right):=\left(a+a^{\prime}\right)+\left(b+b^{\prime}\right) \cdot i \text { az összeadás, } \\
(a+b \cdot i) \cdot\left(a^{\prime}+b^{\prime} \cdot i\right):=\left(a \cdot a^{\prime}-\gamma \cdot b \cdot b^{\prime}\right)+\left(a \cdot b^{\prime}+a^{\prime} \cdot b\right) \cdot i \text { a szorzás. }
\end{gathered}
$$

1. Tétel. Az általánosított komplex számok $\mathbb{C}_{\gamma}$ halmaza a (3), (4) és (5) müveletekkel egy 2dimenziós, neutrális elemes, kommutatív és asszociatív algebrát alkot a valós számok $\mathbb{R}$ teste felett.

Megjegyezzük, hogy a $\mathbb{C}_{\gamma}$ a $\gamma=1$ esetben a klasszikus Gauss-féle komplex számok $\mathbb{C}$ algebráját állítja elő.

A $z=a+b \cdot i \in \mathbb{C}_{\gamma}$ elem konjugáltján a $\bar{z}:=a-b \cdot i \in \mathbb{C}_{\gamma}$ általánosított komplex számot értjük.

A $z=a+b \cdot i \in \mathbb{C}_{\gamma}$ általánosított komplex szám normájának a

$$
N(z):=z \cdot \bar{z}=\bar{z} \cdot z=a^{2}+\gamma \cdot b^{2} \in \mathbb{R}
$$

valós számot nevezzük.

A $z=a+b \cdot i, z^{\prime}=a^{\prime}+b^{\prime} \cdot i \in \mathbb{C}_{\gamma}$ elempár skaláris szorzatán a

valós számot értjük.

$$
\left\langle z, z^{\prime}\right\rangle:=a \cdot a^{\prime}+\gamma \cdot b \cdot b^{\prime} \in \mathbb{R}
$$


Jelölje ezután $M_{2}(\mathbb{R})$ a valós test feletti másodrendü négyzetes mátrixok 4-dimenziós teljes mátrixalgebráját. Az

$$
M_{2}^{\mathbb{C}}(\mathbb{R}):=\left\{\left(\begin{array}{cc}
a & b \\
-\gamma \cdot b & a
\end{array}\right): a, b \in \mathbb{R}\right\} \subset M_{2}(\mathbb{R})
$$

alakú mátrixok halmaza a szokásos mátrixmüveletekkel az $M_{2}(\mathbb{R})$ teljes mátrixalgebrában egy részalgebrát alkot.

2. Tétel. Az $f: \mathbb{C}_{\gamma} \rightarrow M_{2}^{\mathbb{C}}(\mathbb{R}), a+b \cdot i \mapsto\left(\begin{array}{cc}a & b \\ -\gamma \cdot b & a\end{array}\right)$ leképezés egy algebra-izomorfizmus, így $M_{2}^{\mathbb{C}}(\mathbb{R})$ a $\mathbb{C}_{\gamma}$ struktúra mátrixreprezentációja.

Az általánosított komplex számok részletes tárgyalása megtalálható magyarul pl. PÉNTEK (2018) dolgozatában.

$\mathrm{Az}$

$$
\mathbb{M}_{\alpha \beta}:=\{a+b \cdot i+c \cdot j+d \cdot k: a, b, c, d \in \mathbb{R}, i, j, k \notin \mathbb{R}\}
$$

alakú kifejezéseket az általánositott hiperbolikus kvaterniók halmazának nevezzük akkor és csakis akkor, ha az $\{1, i, j, k\}$ általánositott kvaternió-egységek között teljesülnek a következő szorzási összefüggések:

$$
\begin{aligned}
1 \cdot 1=1, \quad 1 \cdot i= & i \cdot 1=i, \quad 1 \cdot j=j \cdot 1=j, \quad 1 \cdot k=k \cdot 1=k \\
& i^{2}=\alpha, \quad j^{2}=\beta, \quad k^{2}=\alpha \cdot \beta \\
i \cdot j=-j \cdot i=k, \quad j \cdot k=-k \cdot j=\beta \cdot i, \quad k \cdot i=-i \cdot k=\alpha \cdot j, &
\end{aligned}
$$

ahol $\alpha, \beta \in \mathbb{R}$ tetszőlegesen rögzített valós számok.

$\mathrm{Az} \mathbb{M}_{\alpha \beta}$ halmazban a skalárral való szorzás, az összeadás, valamint a (8) alapján az algebrák szokásos konstruálási szabályai szerint még a szorzás müvelet értelmezhető az alábbi módon. Tetszöleges $r \in \mathbb{R}, a+b \cdot i+c \cdot j+d \cdot k, a^{\prime}+b^{\prime} \cdot i+c^{\prime} \cdot j+d^{\prime} \cdot k \in \mathbb{M}_{\alpha \beta}$ esetén legyen

(9) $r \cdot(a+b \cdot i+c \cdot j+d \cdot k):=(r \cdot a)+(r \cdot b) \cdot i+(r \cdot c) \cdot j+(r \cdot d) \cdot k$

a skalárral való szorzás,

$$
\begin{aligned}
& (a+b \cdot i+c \cdot j+d \cdot k)+\left(a^{\prime}+b^{\prime} \cdot i+c^{\prime} \cdot j+d^{\prime} \cdot k\right):= \\
& \quad:=\left(a+a^{\prime}\right)+\left(b+b^{\prime}\right) \cdot i+\left(c+c^{\prime}\right) \cdot j+\left(d+d^{\prime}\right) \cdot k
\end{aligned}
$$

az összeadás,

$$
\begin{gathered}
(a+b \cdot i+c \cdot j+d \cdot k) \cdot\left(a^{\prime}+b^{\prime} \cdot i+c^{\prime} \cdot j+d^{\prime} \cdot k\right):= \\
:=\left(a \cdot a^{\prime}+\alpha \cdot b \cdot b^{\prime}+\beta \cdot c \cdot c^{\prime}+\alpha \cdot \beta \cdot d \cdot d^{\prime}\right)+ \\
+\left(a \cdot b^{\prime}+b \cdot a^{\prime}+\beta \cdot c \cdot d^{\prime}-\beta \cdot d \cdot c^{\prime}\right) \cdot i+ \\
+\left(a \cdot c^{\prime}-\alpha \cdot b \cdot d^{\prime}+c \cdot a^{\prime}+\alpha \cdot d \cdot b^{\prime}\right) \cdot j+ \\
\quad+\left(a \cdot d^{\prime}+b \cdot c^{\prime}-c \cdot b^{\prime}+d \cdot a^{\prime}\right) \cdot k
\end{gathered}
$$

a szorzás.

3. Tétel. Az általánosított hiperbolikus kvaterniók $\mathbb{M}_{\alpha \beta}$ halmaza a rajta értelmezett (9), (10) és (11) müveletekkel egy 4-dimenziós, neutrális elemes, de nem kommutatív és nem is asszociatív algebrát alkot a valós számok $\mathbb{R}$ teste felett.

Ebben a struktúrában $0_{\mathbb{M}}:=0+0 \cdot i+0 \cdot j+0 \cdot k \in \mathbb{M}_{\alpha \beta}$ az összeadás neutrális eleme és egyben a szorzás zéruseleme is, $1_{\mathbb{M}}:=1+0 \cdot i+0 \cdot j+0 \cdot k \in \mathbb{M}_{\alpha \beta}$ pedig a szorzás neutrális eleme. 
Megmutatható, hogy az $\mathbb{M}_{\alpha \beta}$ egy olyan kvadratikus algebra, amelyik nem alternáló. Megjegyezzük továbbá, hogy az $\alpha=\beta=1$ esetben az $\mathbb{M}_{\alpha \beta}$ struktúra speciálisan a Macfarlane-féle klasszikus hiperbolikus kvaterniók algebrája lesz.

A $q=a+b \cdot i+c \cdot j+d \cdot k \in \mathbb{M}_{\alpha \beta}$ konjugáltján a

$$
\bar{q}:=a-b \cdot i-c \cdot j-d \cdot k \in \mathbb{M}_{\alpha \beta}
$$

elemet értjük.

A $q=a+b \cdot i+c \cdot j+d \cdot k \in \mathbb{M}_{\alpha \beta}$ normájának a

$$
N(q):=q \cdot \bar{q}=\bar{q} \cdot q=a^{2}-\alpha \cdot b^{2}-\beta \cdot c^{2}-\alpha \cdot \beta \cdot d^{2} \in \mathbb{R}
$$

valós számot nevezzük.

Ha $q=a+b \cdot i+c \cdot j+d \cdot k, q^{\prime}=a^{\prime}+b^{\prime} \cdot i+c^{\prime} \cdot j+d^{\prime} \cdot k \in \mathbb{M}_{\alpha \beta}$, akkor e két elem skaláris szorzatán a

$$
\left\langle q, q^{\prime}\right\rangle:=a \cdot a^{\prime}-\alpha \cdot b \cdot b^{\prime}-\beta \cdot c \cdot c^{\prime}-\alpha \cdot \beta \cdot d \cdot d^{\prime} \in \mathbb{R}
$$

valós számot értjük.

A $q=a+b \cdot i+c \cdot j+d \cdot k \in \mathbb{M}_{\alpha \beta}$ valós részének (skalár rész) a

$$
S(q):=a \in \mathbb{R}
$$

valós számot, képzetes részének (vektor rész) a

$$
V(q):=b \cdot i+c \cdot j+d \cdot k \in \mathbb{R}^{3}
$$

vektort nevezzük. Az

$$
\operatorname{Im}\left(\mathbb{M}_{\alpha \beta}\right):=\left\{0+b \cdot i+c \cdot j+d \cdot k \in \mathbb{M}_{\alpha \beta}\right\} \subset \mathbb{M}_{\alpha \beta}
$$

alakú általánosított hiperbolikus kvaterniókat pedig tiszta képzetes kvaternióknak hívjuk. Ha $q=b \cdot i+c \cdot j+d \cdot k, q^{\prime}=b^{\prime} \cdot i+c^{\prime} \cdot j+d^{\prime} \cdot k \in \operatorname{Im}\left(\mathbb{M}_{\alpha \beta}\right)$, akkor

$$
q \cdot q^{\prime}=-\left[-\alpha \cdot b \cdot b^{\prime}-\beta \cdot c \cdot c^{\prime}-\alpha \cdot \beta \cdot d \cdot d^{\prime}\right]+\left[\left(c \cdot d^{\prime}-d \cdot c^{\prime}\right) \cdot \beta \cdot i+\right.
$$
$\left.+\left(d \cdot b^{\prime}-b \cdot d^{\prime}\right) \cdot \alpha \cdot j+\left(b \cdot c^{\prime}-c \cdot b^{\prime}\right) \cdot k\right]$

Az első szögletes zárójelben szereplő mennyiséget $q \circ q^{\prime}$ jelöli és e két elem skaláris szorzatának, a második szögletes zárójelben szereplö mennyiséget $q \times q^{\prime}$ jelöli és e két elem vektoriális szorzatának nevezzük. Ekkor tehát a $q \cdot q^{\prime}=-q \circ q^{\prime}+q \times q^{\prime}$ összefüggés teljesül.

A

$$
Z(\mathbb{R}):=\left\{\left(\begin{array}{ll}
A_{11} & A_{12} \\
A_{21} & A_{22}
\end{array}\right): A_{11}, A_{22} \in \mathbb{R}, A_{12}, A_{21} \in \mathbb{R}^{3}\right\}
$$

alakú hipermátrixok halmazát valós Zorn-féle vektor-mátrixoknak nevezzük.

4. Tétel. A $Z(\mathbb{R})$ halmaz egy 8-dimenziós, neutrális elemes, de nem kommutatív és nem is asszociatív algebrát alkot a valós számok $\mathbb{R}$ teste felett.

Jelölje $Z_{\mathbb{M}}(\mathbb{R})$ azon speciális valós Zorn-féle vektor-mátrixok halmazát, amelyre teljesülnek az

$$
A_{11}=A_{22}:=a \in \mathbb{R}, A_{12}=-A_{21}:=(b, c, d) \in \mathbb{R}^{3}
$$

feltételek. 
5. Tétel. A $Z_{\mathbb{M}}(\mathbb{R})$ halmaz egy 4-dimenziós, neutrális elemes, de nem kommutatív és nem is asszociatív részalgebrát alkot a $Z(\mathbb{R})$ algebrában. Az

$$
F: \mathbb{M}_{\alpha \beta} \rightarrow Z_{\mathbb{M}}(\mathbb{R}), a+b \cdot i+c \cdot j+d \cdot k \mapsto\left(\begin{array}{cc}
a & (b, c, d) \\
-(b, c, d) & a
\end{array}\right)
$$

leképezés egy algebra-izomorfizmus, így $Z_{\mathbb{M}}(\mathbb{R})$ az $\mathbb{M}_{\alpha \beta}$ struktúra vektor-mátrix reprezentációja.

Az általánosított hiperbolikus kvaterniók részletes tárgyalása magyarul megtalálható pl. PÉNTEK (2020) dolgozatában.

\section{Az általánosított hiperbolikus oktoniók}

Az általánosított hiperbolikus kvaterniók $\mathbb{M}_{\alpha \beta}$ algebrájából kiindulva az általánosított Cayley-Dickson-féle eljárással származtatjuk az általánosított hiperbolikus oktoniókat.

Az $\mathbb{M}_{\alpha \beta} \times \mathbb{M}_{\alpha \beta}:=\left\{\left(q_{0}, q_{1}\right): q_{0}, q_{1} \in \mathbb{M}_{\alpha \beta}\right\}$ direktszorzatban értelmezzünk müveleteket a következö módon

$$
\begin{aligned}
& \text { skalárral való szorzás: } r \cdot\left(q_{0}, q_{1}\right):=\left(r \cdot q_{0}, r \cdot q_{1}\right), \\
& \text { összeadás: }\left(p_{0}, p_{1}\right)+\left(q_{0}, q_{1}\right):=\left(p_{0}+q_{0}, p_{1}+q_{1}\right), \\
& \text { szorzás: }\left(p_{0}, p_{1}\right) \cdot\left(q_{0}, q_{1}\right):=\left(p_{0} \cdot q_{0}-\gamma \cdot \overline{q_{1}} \cdot p_{1}, p_{1} \cdot \overline{q_{0}}+q_{1} \cdot p_{0}\right),
\end{aligned}
$$

ahol $\gamma \in \mathbb{R}$ egy rögzített valós paraméter, $r \in \mathbb{R},\left(p_{0}, p_{1}\right),\left(q_{0}, q_{1}\right) \in \mathbb{M}_{\alpha \beta} \times \mathbb{M}_{\alpha \beta}$.

6. Tétel. Az $\mathbb{M}_{\alpha \beta} \times \mathbb{M}_{\alpha \beta}$ direktszorzat a (22), (23) és (24) müveletekkel egy 8-dimenziós, nem kommutatív és nem is asszociatív, de neutrális elemes algebrát alkot az $\mathbb{R}$ test felett.

E struktúrában $0_{\mathbb{O}}:=\left(0_{\mathbb{M}}, 0_{\mathbb{M}}\right)$ az összeadás, $1_{\mathbb{O}}:=\left(1_{\mathbb{M}}, 0_{\mathbb{M}}\right)$ a szorzás neutrális eleme, továbbá mint 8-dimenziós vektortérben természetes bázist alkot az alábbi elemrendszer: $1_{\mathbb{O}},\left(i, 0_{\mathbb{M}}\right),\left(j, 0_{\mathbb{M}}\right),\left(k, 0_{\mathbb{M}}\right), E:=\left(0_{\mathbb{M}}, 1_{\mathbb{M}}\right),\left(0_{\mathbb{M}}, i\right),\left(0_{\mathbb{M}}, j\right),\left(0_{\mathbb{M}}, k\right)$.

7. Tétel. Az $U:=\left\{\left(q_{0}, 0_{\mathbb{M}}\right): q_{0} \in \mathbb{M}_{\alpha \beta}\right\} \subset \mathbb{M}_{\alpha \beta} \times \mathbb{M}_{\alpha \beta}$ részalgebrát alkot az előző tételben szereplö

$$
f_{\mathbb{Q}}: \mathbb{M}_{\alpha \beta} \rightarrow U, q_{0} \mapsto\left(q_{0}, 0_{\mathbb{M}}\right)
$$

leképezés egy algebra-izomorfizmus, s ezért az

$$
f_{\mathbb{O}}^{*}: \mathbb{M}_{\alpha \beta} \rightarrow \mathbb{M}_{\alpha \beta} \times \mathbb{M}_{\alpha \beta}, q_{0} \mapsto\left(q_{0}, 0_{\mathbb{M}}\right)
$$

egy beágyazási algebra-monomorfizmus.

Definíció. A beágyazás eredményeként kapott struktúrát $\mathbb{O}_{\alpha \beta \gamma}^{H}$ szimbólummal jelöljük és az általánositott hiperbolikus oktoniók algebrájának nevezzük.

8. Tétel. Az $E=\left(0_{\mathbb{M}}, 1_{\mathbb{M}}\right) \in \mathbb{O}_{\alpha \beta \gamma}^{H}$ elemre teljesülnek a következők:

(a) $E^{2}=-\gamma$,

(b) bármely $q_{1} \in \mathbb{M}_{\alpha \beta}$ elemre $\left(0_{\mathbb{M}}, q_{1}\right)=q_{1} \cdot E$,

(c) minden $\left(q_{0}, q_{1}\right) \in \mathbb{O}_{\alpha \beta \gamma}^{H}$ elem elöállítható $q_{0}+q_{1} \cdot E$ alakban. 
A (c) pontban szereplő előállítást az általánosított hiperbolikus oktonió kvaternió-algebrai alakjának nevezzük. Az ezen alakkal történő számolás szabályait mutatja a következő

9. Tétel. Ha $r \in \mathbb{R}, p_{0}+p_{1} \cdot E, q_{0}+q_{1} \cdot E \in \mathbb{O}_{\alpha \beta \gamma}^{H}$, akkor

(a) skalárral való szorzás: $r \cdot\left(q_{0}+q_{1} \cdot E\right)=\left(r \cdot q_{0}\right)+\left(r \cdot q_{1}\right) \cdot E$,

(b) összeadás: $\left(p_{0}+p_{1} \cdot E\right)+\left(q_{0}+q_{1} \cdot E\right)=\left(p_{0}+q_{0}\right)+\left(p_{1}+q_{1}\right) \cdot E$,

(c) szorzás: $\left(p_{0}+p_{1} \cdot E\right) \cdot\left(q_{0}+q_{1} \cdot E\right)=$

$$
=\left(p_{0} \cdot q_{0}-\gamma \cdot \overline{q_{1}} \cdot p_{1}\right)+\left(p_{1} \cdot \overline{q_{0}}+q_{1} \cdot p_{0}\right) \cdot E .
$$

Speciálisan a $p_{0}:=0_{\mathbb{M}}, p_{1}:=1_{\mathbb{M}}, q_{0}:=q, q_{1}:=0_{\mathbb{M}}$ értékadással az előző tétel (c) része alapján érvényes a

10. Következmény. Bármely $q \in \mathbb{M}_{\alpha \beta}$ elemre érvényes: $E \cdot q=\bar{q} \cdot E$.

Megjegyzés. Ha $q$ értéke $i, j$ vagy $k$, akkor a fenti következmény alapján

$$
E \cdot i=-i \cdot E, E \cdot j=-j \cdot E, E \cdot k=-k \cdot E .
$$

Egyszerü direkt számolással igazolható a következő

\section{Lemma.}

(a) Ha $f \in \mathbb{R}, i \in \mathbb{M}_{\alpha \beta}, E \in \mathbb{O}_{\alpha \beta \gamma}^{H}$, akkor $(f \cdot i) \cdot E=f \cdot(i \cdot E)$,

(b) ha $g \in \mathbb{R}, j \in \mathbb{M}_{\alpha \beta}, E \in \mathbb{O}_{\alpha \beta \gamma}^{H}$, akkor $(g \cdot j) \cdot E=g \cdot(j \cdot E)$,

(c) ha $h \in \mathbb{R}, k \in \mathbb{M}_{\alpha \beta}, E \in \mathbb{O}_{\alpha \beta \gamma}^{H}$, akkor $(h \cdot k) \cdot E=h \cdot(k \cdot E)$.

A 8. Tétel és a 11. Lemma alapján közvetlenül adódik a

12. Tétel. Ha $q_{0}=a_{0}+a_{1} \cdot i+a_{2} \cdot j+a_{3} \cdot k, q_{1}=a_{4}+a_{5} \cdot i+a_{6} \cdot j+a_{7} \cdot k \in \mathbb{M}_{\alpha \beta}$ akkor a

általánosított hiperbolikus oktonió felírható

$$
o:=q_{0}+q_{1} \cdot E \in \mathbb{O}_{\alpha \beta \gamma}^{H}
$$

$$
o=a_{0}+a_{1} \cdot i+a_{2} \cdot j+a_{3} \cdot k+a_{4} \cdot E+a_{5} \cdot(i \cdot E)+a_{6} \cdot(j \cdot E)+a_{7} \cdot(k \cdot E)
$$

alakban.

Legyen a továbbiakban

$$
e_{0}:=1, e_{1}:=i, e_{2}:=j, e_{3}:=k, e_{4}:=E, e_{5}:=i \cdot E, e_{6}:=j \cdot E, e_{7}:=k \cdot E,
$$

amellyel az általánosított hiperbolikus oktoniók fenti elóállítása lényegesen tömörebb és könnyebben kezelhető

$$
o=\sum_{i=0}^{7} a_{i} \cdot e_{i}
$$

alakban állíthatók elő. A (25) alakot az $o \in \mathbb{O}_{\alpha \beta \gamma}^{H}$ oktonió valós-algebrai alakjának nevezzük, az $\left\{e_{i}\right\}_{i=0}^{7}$ elemeket általánosított hiperbolikus oktonióegységeknek nevezzük.

A 11. Lemma folytatásaként egyszerü direkt számítással igazolható, hogy az általánosított hiperbolikus oktoniók körében is érvényesek (EBBINGHAUS ET AL, 1991) mintájára az alábbi összefüggések:

13. Tétel. Tetszőleges $u, v \in \mathbb{M}_{\alpha \beta}$ és az $e_{4}=E \in \mathbb{O}_{\alpha \beta \gamma}^{H}$ esetén:

(a) $\left(u+0_{\mathbb{M}} \cdot e_{4}\right) \cdot\left(v+0_{\mathbb{M}} \cdot e_{4}\right)=u \cdot v+0_{\mathbb{M}} \cdot e_{4}=u \cdot v$, 
(b) $\left(u+0_{\mathbb{M}} \cdot e_{4}\right) \cdot\left(0_{\mathbb{M}}+v \cdot e_{4}\right)=u \cdot\left(v \cdot e_{4}\right)=(v \cdot u) \cdot e_{4}$,

(c) $\left(0_{\mathbb{M}}+u \cdot e_{4}\right) \cdot\left(v+0_{\mathbb{M}} \cdot e_{4}\right)=\left(u \cdot e_{4}\right) \cdot v=(u \cdot \bar{v}) \cdot e_{4}$,

(d) $\left(0_{\mathbb{M}}+u \cdot e_{4}\right) \cdot\left(0_{\mathbb{M}}+v \cdot e_{4}\right)=\left(u \cdot e_{4}\right) \cdot\left(v \cdot e_{4}\right)=e_{4}^{2} \cdot(\bar{v} \cdot u)$.

Megjegyzés. Vegyük észre, hogy az (a) rész szerint az olyan általánosított hiperbolikus oktoniókkal, amelyek „,képzetes része” 0 , úgy számolhatunk, mint az általánosított hiperbolikus kvaterniókkal.

14. Tétel. Az általánosított hiperbolikus oktonióegységek Cayley-féle szorzótáblájának belső tartománya:

\begin{tabular}{|c|c|c|c|c|c|c|c|}
\hline$e_{0}$ & $e_{1}$ & $e_{2}$ & $e_{3}$ & $e_{4}$ & $e_{5}$ & $e_{6}$ & $e_{7}$ \\
\hline$e_{1}$ & $\alpha e_{0}$ & $e_{3}$ & $-\alpha e_{2}$ & $e_{5}$ & $\alpha e_{4}$ & $-e_{7}$ & $\alpha e_{6}$ \\
\hline$e_{2}$ & $-e_{3}$ & $\beta e_{0}$ & $\beta e_{1}$ & $e_{6}$ & $e_{7}$ & $\beta e_{4}$ & $-\beta e_{5}$ \\
\hline$e_{3}$ & $\alpha e_{2}$ & $-\beta e_{1}$ & $\alpha \beta e_{0}$ & $e_{7}$ & $-\alpha e_{6}$ & $\beta e_{5}$ & $\alpha \beta e_{4}$ \\
\hline$e_{4}$ & $-e_{5}$ & $-e_{6}$ & $-e_{7}$ & $-\gamma e_{0}$ & $\gamma e_{1}$ & $\gamma e_{2}$ & $\gamma e_{3}$ \\
\hline$e_{5}$ & $-\alpha e_{4}$ & $-e_{7}$ & $\alpha e_{6}$ & $-\gamma e_{1}$ & $\gamma \alpha e_{0}$ & $-\gamma e_{3}$ & $\gamma \alpha e_{2}$ \\
\hline$e_{6}$ & $e_{7}$ & $-\beta e_{4}$ & $-\beta e_{5}$ & $-\gamma e_{2}$ & $\gamma e_{3}$ & $\gamma \beta e_{0}$ & $-\gamma \beta e_{1}$ \\
\hline$e_{7}$ & $-\alpha e_{6}$ & $\beta e_{5}$ & $-\alpha \beta e_{4}$ & $-\gamma e_{3}$ & $-\gamma \alpha e_{2}$ & $\gamma \beta e_{1}$ & $\gamma \alpha \beta e_{0}$ \\
\hline
\end{tabular}

Bizonyítás. A 13. tétel (a) része szerint a müveleti táblázat bal felső $4 \times 4$-es parcellája azonos az $\mathbb{M}_{\alpha \beta}$ általánosított hiperbolikus kvaterniók egységeinek szorzótáblájával. A 13. tétel (b) részének felhasználásával egyszerü közvetlen számítással igazolhatjuk a müveleti táblázat jobb felső $4 \times 4$-es parcellájának helyességét. Ezután a 13. tétel (c) részét alkalmazva igazolhatjuk a müveleti táblázat bal alsó $4 \times 4$-es parcella kitöltésének helyességét. Végül pedig a müveleti táblázat jobb alsó $4 \times 4$-es parcellájának helyessége a 13. tétel (d) része alapján látható be.

Hosszadalmas, bár nem nehéz számításokkal a 14. tétel, valamint a szorzás összeadásra való disztributív tulajdonságát felhasználva adódik a következő

15. Tétel. Legyen $r \in \mathbb{R}, a=\sum_{i=0}^{7} a_{i} \cdot e_{i}, b=\sum_{i=0}^{7} b_{i} \cdot e_{i} \in \mathbb{O}_{\alpha \beta \gamma}^{H}$, akkor érvényesek a következő számolási szabályok:

(a) skalárral való szorzás:

(b) összeadás:

$$
r \cdot\left(\sum_{i=0}^{7} a_{i} \cdot e_{i}\right)=\sum_{i=0}^{7}\left(r \cdot a_{i}\right) \cdot e_{i}
$$

(c) szorzás:

$$
a+b=\sum_{i=0}^{7} a_{i} \cdot e_{i}+\sum_{i=0}^{7} b_{i} \cdot e_{i}=\sum_{i=0}^{7}\left(a_{i}+b_{i}\right) \cdot e_{i},
$$

$$
\begin{gathered}
a \cdot b=\left(\sum_{i=0}^{7} a_{i} \cdot e_{i}\right) \cdot\left(\sum_{j=0}^{7} b_{j} \cdot e_{j}\right)=\sum_{i, j=0}^{7}\left(a_{i} \cdot b_{j}\right) \cdot\left(e_{i} \cdot e_{j}\right)= \\
=\left(a_{0} b_{0}+\alpha a_{1} b_{1}+\beta a_{2} b_{2}+\alpha \beta a_{3} b_{3}-\gamma a_{4} b_{4}+\gamma \alpha a_{5} b_{5}+\gamma \beta a_{6} b_{6}+\gamma \alpha \beta a_{7} b_{7}\right) \cdot e_{0}+ \\
+\left(a_{0} b_{1}+a_{1} b_{0}+\beta a_{2} b_{3}-\beta a_{3} b_{2}+\gamma a_{4} b_{5}-\gamma a_{5} b_{4}-\gamma \beta a_{6} b_{7}+\gamma \beta a_{7} b_{6}\right) \cdot e_{1}+ \\
+\left(a_{0} b_{2}-\alpha a_{1} b_{3}+a_{2} b_{0}+\alpha a_{3} b_{1}+\gamma a_{4} b_{6}+\gamma \alpha a_{5} b_{7}-\gamma a_{6} b_{4}-\gamma \alpha a_{7} b_{5}\right) \cdot e_{2}+ \\
+\left(a_{0} b_{3}+a_{1} b_{2}-a_{2} b_{1}+a_{3} b_{0}+\gamma a_{4} b_{7}-\gamma a_{5} b_{6}+\gamma a_{6} b_{5}-\gamma a_{7} b_{4}\right) \cdot e_{3}+ \\
+\left(a_{0} b_{4}+\alpha a_{1} b_{5}+\beta a_{2} b_{6}+\alpha \beta a_{3} b_{7}+a_{4} b_{0}-\alpha a_{5} b_{1}-\beta a_{6} b_{2}-\alpha \beta a_{7} b_{3}\right) \cdot e_{4}+ \\
+\left(a_{0} b_{5}+a_{1} b_{4}-\beta a_{2} b_{7}+\beta a_{3} b_{6}-a_{4} b_{1}+a_{5} b_{0}-\beta a_{6} b_{3}+\beta a_{7} b_{2}\right) \cdot e_{5}+ \\
+\left(a_{0} b_{6}+\alpha a_{1} b_{7}+a_{2} b_{4}-\alpha a_{3} b_{5}-a_{4} b_{2}+\alpha a_{5} b_{3}+a_{6} b_{0}-\alpha a_{7} b_{0}\right) \cdot e_{6}+ \\
+\left(a_{0} b_{7}-a_{1} b_{6}+a_{2} b_{5}+a_{3} b_{4}-a_{4} b_{3}-a_{5} b_{2}+a_{6} b_{1}+a_{7} b_{0}\right) \cdot e_{7}
\end{gathered}
$$


Definíció. Az $o=q_{0}+q_{1} \cdot e_{4} \in \mathbb{O}_{\alpha \beta \gamma}^{H}$ konjugáltján az $\bar{o}:=\overline{q_{0}}-q_{1} \cdot e_{4} \in \mathbb{O}_{\alpha \beta \gamma}^{H}$ általánosított hiperbolikus oktoniót értjük. Ha $q_{0}=\sum_{i=0}^{3} a_{i} \cdot e_{i}$ és $q_{1}=\sum_{i=0}^{3} a_{i+4} \cdot e_{i} \in \mathbb{M}_{\alpha \beta}$, akkor egyszerüen látható, hogy $\bar{o}=a_{0} \cdot e_{0}-\sum_{i=1}^{7} a_{i} \cdot e_{i}$.

A konjugált képzésére érvényesek az alábbi összefüggések:

16. Tétel. Ha $r \in \mathbb{R}$ és $o, o^{\prime} \in \mathbb{O}_{\alpha \beta \gamma}^{H}$ tetszőleges elemek, akkor
(a) $\overline{\bar{o}}=o$ involutív,
(b) $\overline{r \cdot o}=r \cdot \bar{o} \quad$ homogén,
(c) $\overline{o+o^{\prime}}=\bar{o}+\overline{o^{\prime}}$ additív,
(d) $\overline{o \cdot o^{\prime}}=\overline{o^{\prime}} \cdot \bar{o} \quad$ anti-multiplikatív.

17. Tétel. Ha $o=q_{0}+q_{1} \cdot e_{4} \in \mathbb{O}_{\alpha \beta \gamma}^{H}, q_{0}=\sum_{i=0}^{3} a_{i} \cdot e_{i}, q_{1}=\sum_{i=0}^{3} a_{i+4} \cdot e_{i} \in \mathbb{M}_{\alpha \beta}$, akkor teljesül az $o \cdot \bar{o}=\bar{o} \cdot o=a_{0}^{2}-\alpha \cdot a_{1}^{2}-\beta \cdot a_{2}^{2}-\alpha \cdot \beta \cdot a_{3}^{2}+\gamma \cdot a_{4}^{2}-\alpha \gamma \cdot a_{5}^{2}-\beta \gamma \cdot a_{6}^{2}-$ $\alpha \beta \gamma \cdot a_{7}^{2} \in \mathbb{R}$.

Definíció:

Definíció. Az $o \in \mathbb{O}_{\alpha \beta \gamma}^{H}$ általánosított hiperbolikus oktonió normáján a 17. tételben szereplő

valós számot értjük.

$$
N(o):=o \cdot \bar{o}=\bar{o} \cdot o \in \mathbb{R}
$$

18. Tétel. Az általánosított hiperbolikus oktoniók normája rendelkezik az alábbi tulajdonságokkal:

(a) Tetszőleges $o \in \mathbb{O}_{\alpha \beta \gamma}^{H}$ esetén teljesül $N(o)=N(\bar{o})$,

(b) Ha $o, o^{\prime} \in \mathbb{O}_{\alpha \beta \gamma}^{H}$, akkor általában $N\left(o \cdot o^{\prime}\right) \neq N(o) \cdot N\left(o^{\prime}\right)$.

Megjegyzés. A 18. tétel (b) pontját egyszerüen beláthatjuk, hiszen $N\left(e_{1} \cdot e_{2}\right)=N\left(e_{3}\right)=-\alpha \beta$, másrészt $N\left(e_{1}\right)=-\alpha$ és $N\left(e_{2}\right)=-\beta$, így $N\left(e_{1}\right) \cdot N\left(e_{2}\right)=(-\alpha) \cdot(-\beta)=\alpha \beta$, tehát valóban $N\left(e_{1} \cdot e_{2}\right) \neq N\left(e_{1}\right) \cdot N\left(e_{2}\right)$.

Definíció. Ha $o=\sum_{i=0}^{7} a_{i} \cdot e_{i}$ és $o^{\prime}=\sum_{i=0}^{7} b_{i} \cdot e_{i} \in \mathbb{O}_{\alpha \beta \gamma}^{H}$, akkor e két általánosított hiperbolikus oktonió skaláris szorzatán az $\left\langle o, o^{\prime}\right\rangle:=a_{o} b_{0}-\alpha a_{1} b_{1}-\beta a_{2} b_{2}-\alpha \beta a_{3} b_{3}+\gamma a_{4} b_{4}-\alpha \gamma a_{5} b_{5}-\beta \gamma a_{6} b_{6}-\alpha \beta \gamma a_{7} b_{7} \in \mathbb{R}$ valós számot értjük.

Egyszerü direkt számolással láthatjuk be a következő állítást:

19. Tétel. A $\mathcal{B}: \mathbb{O}_{\alpha \beta \gamma}^{H} \times \mathbb{O}_{\alpha \beta \gamma}^{H} \rightarrow \mathbb{R},\left(o, o^{\prime}\right) \mapsto\left\langle o, o^{\prime}\right\rangle$ egy szimmetrikus, bilineáris leképezés: tetszőleges $r \in \mathbb{R}, o, o^{\prime}, o^{\prime \prime} \in \mathbb{O}_{\alpha \beta \gamma}^{H}$ esetén

(a) $\left\langle o, o^{\prime}\right\rangle=\left\langle o^{\prime}, o\right\rangle$

kommutatív,

(b) $\left\langle r \cdot o, o^{\prime}\right\rangle=\left\langle o, r \cdot o^{\prime}\right\rangle=r \cdot\left\langle o, o^{\prime}\right\rangle$ homogén,

(c) $\left\langle o+o^{\prime}, o^{\prime \prime}\right\rangle=\left\langle o, o^{\prime \prime}\right\rangle+\left\langle o^{\prime}, o^{\prime \prime}\right\rangle \quad$ jobbról disztributív az összeadásra nézve,

(d) $\left\langle o, o^{\prime}+o^{\prime \prime}\right\rangle=\left\langle o, o^{\prime}\right\rangle+\left\langle o, o^{\prime \prime}\right\rangle \quad$ balról disztributív az összeadásra nézve.

Vegyük észre, hogy ha $o \in \mathbb{O}_{\alpha \beta \gamma}^{H}$, akkor $N(o)=\langle o, o\rangle$, tehát az általánosított hiperbolikus oktoniók normája a skaláris szorzatból származtatható. 


\section{Az általánosított hiperbolikus oktoniók vektor-mátrix reprezentációja}

A $\gamma \in \mathbb{R}$ valós paraméter segítségével konstruáljuk meg a 2. fejezetben látott módon az általánosított komplex számok $\mathbb{C}_{\gamma}$ algebráját, s vegyük a $\mathbb{C}_{\gamma}$ elemeiből felépülő

$$
Z\left(\mathbb{C}_{\gamma}\right):=\left\{\left(\begin{array}{ll}
A_{11} & A_{12} \\
A_{21} & A_{22}
\end{array}\right): A_{11}, A_{22} \in \mathbb{C}_{\gamma}, A_{12}, A_{21} \in \mathbb{C}_{\gamma}^{3}\right\}
$$

alakú hipermátrixok halmazát! Értelmezzünk ezután ezen hipermátrixok halmazában egy skalárral való szorzást és egy összeadást a következő módon! Ha $r \in \mathbb{R}, A, B \in Z\left(\mathbb{C}_{\gamma}\right)$, akkor $r \cdot A=r \cdot\left(\begin{array}{ll}A_{11} & A_{12} \\ A_{21} & A_{22}\end{array}\right):=\left(\begin{array}{ll}r \cdot A_{11} & r \cdot A_{12} \\ r \cdot A_{21} & r \cdot A_{22}\end{array}\right)$ a skalárral történő szorzást,

$A+B=\left(\begin{array}{ll}A_{11} & A_{12} \\ A_{21} & A_{22}\end{array}\right)+\left(\begin{array}{ll}B_{11} & B_{12} \\ B_{21} & B_{22}\end{array}\right):=\left(\begin{array}{ll}A_{11}+B_{11} & A_{12}+B_{12} \\ A_{21}+B_{21} & A_{22}+B_{22}\end{array}\right) \quad$ az $\quad$ összeadást értelmezi.

20. Tétel. A $Z\left(\mathbb{C}_{\gamma}\right)$ halmaz a rajta értelmezett skalárral való szorzás és összeadás műveletekkel egy 16-dimenziós vektorteret alkot a valós számok $\mathbb{R}$ teste felett.

Tekintsük most a $Z\left(\mathbb{C}_{\gamma}\right)$ elemei közül azon különleges alakú hipermátrixokat, amelyekre teljesül, hogy $A_{22} \in \mathbb{C}_{\gamma}$ az $A_{11} \in \mathbb{C}_{\gamma}$ konjugáltja, $A_{12} \in \mathbb{C}_{\gamma}^{3}$ komponensei az $A_{21} \in \mathbb{C}_{\gamma}^{3}$ komponenseinek negatív konjugáltjai. Ezek halmazát jelölje a továbbiakban $Z_{*}\left(\mathbb{C}_{\gamma}\right)$ !

21. Tétel. A $Z_{*}\left(\mathbb{C}_{\gamma}\right)$ halmaz a skalárral való szorzás és összeadás műveletével egy 8-dimenziós alteret alkot $Z\left(\mathbb{C}_{\gamma}\right)$ vektortérben.

Ezt a struktúrát algebrává fejleszthetjük, ha elemei között értelmezünk egy * szorzás müveletet a következő módon:

$$
\begin{aligned}
& A * B=\left(\begin{array}{ll}
A_{11} & A_{12} \\
A_{21} & A_{22}
\end{array}\right) *\left(\begin{array}{ll}
B_{11} & B_{12} \\
B_{21} & B_{22}
\end{array}\right):= \\
&:=\left(\begin{array}{cc}
A_{11} \cdot B_{11}+A_{12} \circ B_{21} & A_{11} \cdot B_{12}+B_{22} \cdot A_{12}-A_{21} \times B_{21} \\
B_{11} \cdot A_{21}+A_{22} \cdot B_{21}+A_{12} \times B_{12} & A_{22} \cdot B_{22}+A_{21} \circ B_{12}
\end{array}\right) .
\end{aligned}
$$

Látható, hogy a * szorzás emlékeztet a mátrixok klasszikus szorzására, de itt a ० és $\times$ müveleteket a következőképpen értelmezzük:

Ha $U=\left(u_{1}, u_{2}, u_{3}\right), V=\left(v_{1}, v_{2}, v_{3}\right) \in \mathbb{C}_{\gamma}^{3}$, akkor legyen

$$
\begin{gathered}
U \circ V:=-\alpha \cdot u_{1} \cdot v_{1}-\beta \cdot u_{2} \cdot v_{2}-\alpha \cdot \beta \cdot u_{3} \cdot v_{3} \in \mathbb{C}_{\gamma}, \\
U \times V:=\left(\left(u_{2} \cdot v_{3}-u_{3} \cdot v_{2}\right) \cdot \beta,\left(u_{3} \cdot v_{1}-u_{1} \cdot v_{3}\right) \cdot \alpha, u_{1} \cdot v_{2}-u_{2} \cdot v_{1}\right) \in \mathbb{C}_{\gamma}^{3} .
\end{gathered}
$$

E skaláris és vektoriális szorzásnak nevezhető müvelet teljesen analóg az $\operatorname{Im}\left(\mathbb{M}_{\alpha \beta}\right)$ struktúra 2. fejezet (18) formulájával értelmezett skaláris és vektoriális szorzatával.

22. Tétel. A $Z_{*}\left(\mathbb{C}_{\gamma}\right)$ vektortér a $*$ szorzási müvelettel egy 8 -dimenziós nem kommutatív és nem asszociatív algebrát alkot a valós számok $\mathbb{R}$ teste felett.

Ezt a struktúrát általánositott komplex hiperbolikus Zorn-féle vektor-mátrixok algebrájának nevezzük, kiterjesztve ZORN (1933) eredményeit. 
Tekintsük KARATAS - HALICI (2018) dolgozatában bemutatott mintájára az

$$
\begin{gathered}
F: \mathbb{O}_{\alpha \beta \gamma}^{H} \rightarrow Z_{*}\left(\mathbb{C}_{\gamma}\right), \\
\sum_{j=0}^{7} a_{i} e_{i} \mapsto\left(\begin{array}{cc}
a_{0}+a_{4} i & \left(-a_{1}+a_{5} i,-a_{2}+a_{6} i,-a_{3}+a_{7} i\right) \\
\left(a_{1}+a_{5} i, a_{2}+a_{6} i, a_{3}+a_{7} i\right) & a_{0}-a_{4} i
\end{array}\right)
\end{gathered}
$$

leképezést! Az $F$ egy bijektív leképezés, hiszen $F^{-1}$ is leképezés. Hosszadalmas direkt számítással igazolható, hogy $F$ egy müvelettartó leképezés is, mivel érvényesek az alábbi összefüggések: tetszöleges $r \in \mathbb{R}, o, o_{1}, o_{2} \in \mathbb{O}_{\alpha \beta \gamma}^{H}$ esetén
(a) homogén:
$F(r \cdot o)=r \cdot F(o)$,
(b) additív:
$F\left(o_{1}+o_{2}\right)=F\left(o_{1}\right)+F\left(o_{2}\right)$,
(c) multiplikatív:
$F\left(o_{1} \cdot o_{2}\right)=F\left(o_{1}\right) * F\left(o_{2}\right)$.

Ezért érvényes a dolgozat fö eredményét összegző

23. Tétel. Az $F: \mathbb{O}_{\alpha \beta \gamma}^{H} \rightarrow Z_{*}\left(\mathbb{C}_{\gamma}\right)$ leképezés egy algebra-izomorfizmus, így az általánosított komplex hiperbolikus Zorn-féle vektor-mátrixok algebrája az általánosított hiperbolikus oktoniók algebrájának egy reprezentációja.

\section{Irodalomjegyzék}

[1] Cayley, A. (1889): On Jacobi's elliptic function, in reply to the Rev. B. Bronwin; and on quaternions. The collected Mathematical Papers of Arthur Cayley 1: 127.

[2] Ebbinghause, H.D. Hermes, H. Hirzebruch, F. Koecher, M. Mainzer, M. Mainzer, K. Neukirch, J. Prestel, A. Remmert, R. (1991): Numbers. Springer.

[3] Hamilton, W. R, (1844): On a new Species of Imaginary quantities connected with a Theory of quaternions. Proceedings of the Royal Irish Academy 2, 424-434.

[4] Hamilton, W. R. (1847): On Quaternions. Proceedings of the Royal Irish Academy 3, 1-16.

[5] Kántor, I. L., Szolodovnyikov, A. Sz. (1985): Hiperkomplex számok. Gondolat, Budapest, 1985.

[6] Karatas, A. Halici, S. (2018): Vector matrix representation of octonions and their geometry. Commun. Fac. Sci. Univ. Ank. Ser. A1 67(1): 161-167. doi:10.1501/Commua1_0000000839

[7] Macfarlane, A. (2018): Hyperbolic Quaternions. Proceedings of the Royal Society at Edinburgh. vol. 23. 169 - 180 +figures plate. doi:10.1017/S0370164600010385

[8] Péntek, K., (2018): Az általánosított kvaternióalgebrák egy új felépítéséről. Dimenziók. Matematikai Közlemények. VI. 25-30. doi:10.20312/dim.2018.03

[9] Péntek, K., (2020): Az általánosított hiperbolikus kvaternióalgebrákról. Dimenziók. Matematikai Közlemények. VIII. 25-33. doi:10.20312/dim.2020.03

[10] Rosenfeld, B. (1997): Geometry of Lie groups. Kluwer Academic Publisher, Netherlands. doi:10.1007/978$1-4757-5325-7$

[11]Zorn, M. A., (1933): Alternativkörper und quadratische systeme. In: Abhandlungen aus dem Mathematischen Seminar der Universitat Hamburg. Springer Berlin/Heidelberg. 395-402. 